\title{
PRODUCTION OF DICALCIUM PHOSPHATE FROM LAO CAI SECOND GRADE APATITE ORE LEACHED BY DILUTE HYDROCHLORIC ACID
}

\author{
Trinh Xuan Hiep, ${ }^{1, *}$, Nguyen Xuan Truong ${ }^{1}$, Nguyen Van Dung ${ }^{2}$, Vu Van Chinh ${ }^{2}$ \\ ${ }^{1}$ Institute of Materials Science - Vietnam Academy of Science and Technology, \\ 18 Hoang Quoc Viet street, Cau Giay District, Ha Noi \\ ${ }^{2}$ Ha Noi AT Applied Technology Joint Stock Company, No 4 - 54/218 Lac Long Quan stree, \\ Tay Ho District, Ha Noi \\ "Email: trixuhi@gmail.com
}

Received: 9 May 2016; Accepted for publication: 1 February 2017

\begin{abstract}
The production of dicalcium phosphate from Lao Cai second grade apatite was investigated by leaching with dilute hydrochloric acid. Various factors affecting the process such as particle size, leaching time, leaching temperature, phosphate rock/hydrochloric acid ratio and mixing stirring speed and temperature have been studied to estimate the favor phosphate ore dissolution in relation to impurity. These parameters were fixed at a leaching time of $16 \mathrm{~min}$, stirring speed of $400 \mathrm{rpm}$, temperature of $25{ }^{\circ} \mathrm{C}$, hydrochloric acid concentration of $10 \%$ and acid/phosphate ore mass ratio of $25 \mathrm{ml} / 5 \mathrm{~g}$ and particle size $\leq 450 \mu \mathrm{m}$. The produced aqueous acidic solution was neutralized in such a way that a pure dicalcium phosphate $\mathrm{CaHPO}_{4}$, which precipitated to be used as animal fooder. The production efficiency was $96.8 \%$.
\end{abstract}

Keywords: Lao Cai second grade apatite, carbonate-phosphate ore, low-grade phosphate ore, dicalcium phosphate production, dilute hydrochloric acid leaching.

\section{INTRODUCTION}

Dicalcium phosphate is the calcium phosphate with the formula $\mathrm{CaHPO}_{4}$. The "di" prefix in the common name arises because the formation of the $\mathrm{HPO}_{4}{ }^{2-}$ anion involves the removal of two protons from phosphoric acid, $\mathrm{H}_{3} \mathrm{PO}_{4}$. It is also known as dibasic calcium phosphate or calcium monohydrogen phosphate. There are three crystalline forms: a dihydrate, $\mathrm{CaHPO}_{4} \cdot 2 \mathrm{H}_{2} \mathrm{O}$ (DPCD), the mineral brushite; a hemihydrate, $\mathrm{CaHPO}_{4} \cdot 0.5 \mathrm{H}_{2} \mathrm{O}$; and anhydrous $\mathrm{CaHPO}_{4}$, (DCPA), the mineral monetite. The production of dicalcium phosphate for use as animal fodders, by direct acidulation of phosphate rock with mineral acids has long been a goal of the fertilizer industry, since it uses much less mineral acid consumption than by conventional other processes [1 - 5].

Production of dicalcium phosphate for use as animal fodders through phosphoric acid prepared by wet processes. The wet process by sulfuric acid presents $90 \%$ of the world current phosphoric acid production [5-6]. When phosphate rock is treated with sulfuric acid, phosphoric acid is formed according to the following equation: 


$$
\mathrm{Ca}_{10}\left(\mathrm{PO}_{4}\right)_{6} \mathrm{~F}_{2}+10 \mathrm{H}_{2} \mathrm{SO}_{4} \leftrightarrow 6 \mathrm{H}_{3} \mathrm{PO}_{4}+10 \mathrm{CaSO}_{4}+2 \mathrm{HF}
$$

Animal grade dicalcium phosphate has successfully produced from phosphoric acid produced by Phuc Lam Chemicals Company (Tangloong Town, Bao Thang District, Lao Cai Province) by two steps. The first step includes clarification and defluorination of crude phosphoric acid. The second step includes the precipitation of animal grade calcium phosphate by using different calcium salts as lime and calcium carbonate.

Phosphate ores are of two major geological origins, igneous and sedimentary. The phosphate minerals in both types of ore are of the apatite group, of which the most commonly encountered variants are fluorapatite, $\mathrm{Ca}_{10}\left(\mathrm{PO}_{4}\right)_{6}(\mathrm{~F}, \mathrm{OH})_{2}$ and francolite, $\left.\mathrm{Ca}_{10}\left(\mathrm{PO}_{4}\right)_{6}\left(\mathrm{CO}_{3}\right)_{\mathrm{x}}(\mathrm{F}, \mathrm{OH})_{2-\mathrm{x}}\right)$, where fluorapatite predominates in igneous phosphate rocks and francolite predominates in sedimentary phosphate rocks [1 - 4].

In Vietnam, phosphate ores occur in main Lao Cai province. The Lao Cai deposit is one of the largest phosphate deposits of South-East Asia. Lao Cai phosphate rock is classified into four grades known as first grade ore $\left(34-36 \% \mathrm{P}_{2} \mathrm{O}_{5}\right)$, second grade ore $\left(23-24 \% \mathrm{P}_{2} \mathrm{O}_{5}\right)$, third grade ore $\left(15-17 \% \mathrm{P}_{2} \mathrm{O}_{5}\right)$, and fourth grade ore $\left(10-12 \% \mathrm{P}_{2} \mathrm{O}_{5}\right)$. The apatite beds are the metamorphosed phosphorites, hosted in the cambrian metasediments (schists, marbles ...), occurring over $100 \mathrm{~km}$ in Vietnam (and continuing in China). Total reserves of phosphate are put at 1.7 billion tons, second grade ore make up more than $50 \%$, which is a carbonatephosphate rock. Carbonates (calcite $\&$ dolomite) are considered the most problematic ones among the impurities associated with phosphate. They are coursing sulfuric acid consumption in acidulation of phosphate rock, increase $\mathrm{P}_{2} \mathrm{O}_{5}$ loss, increase fluid viscosity, which lowers filtration rates when separating solid gypsum crystals from the valuable phosphoric acid.

Separating carbonate impurities from phosphate has long been recognized as one of the most challenging subjects in phosphate ore beneficiation because their similarities in physical and chemical properties.

The aim of the present work is to investigate different conditions as particle size, leaching time, leaching temperature, phosphate rock $/ \mathrm{HCl}$ ratio and mixing speed (rpm) that affect the production of phosphoric acid and/or the phosphate salt from Lao Cai second grade ore by attacking with dilute hydrochloric acid to estimate the favor phosphate ore leaching in relation to an impurity and direct production for dicalcium phosphate (DCP).

\section{EXPERIMENTAL}

\subsection{Materials}

$\mathrm{HCl}, \mathrm{H}_{2} \mathrm{SO}_{4}, \mathrm{H}_{3} \mathrm{PO}_{4}$ (Xilong, China) were chemical reagents grade. $\mathrm{CaCO}_{3}$ and $\mathrm{Ca}(\mathrm{OH})_{2}$ (Xilong, China) were used as a source of calcium ions.

A composite sample of Lao Cai second grade ore from Unit CS-5 was delivered from Vietnam Apatite Limited Company (VINAAPACO). The chemical analysis of the phosphate rock is shown in Table 1.

XRD analysis of the sample indicated that: the main mineral of the Lao Cai second grade apatite ore from Unit CS-5 is fluorapatite and francolite together with minor amounts of dolomite and calcite as shown in Fig. 1. 
Table 1. Chemical analysis of Lao Cai second grade apatite ore from Unit CS-5.

\begin{tabular}{|c|c|}
\hline Constituent & \% \\
\hline $\mathrm{P}_{2} \mathrm{O}_{5}$ & 23.19 \\
$\mathrm{CaO}$ & 43.17 \\
$\mathrm{MgO}$ & 5.61 \\
$\mathrm{Fe}_{2} \mathrm{O}_{3}$ & 1.42 \\
$\mathrm{~F}$ & 1.91 \\
$\mathrm{SiO} 2$ & 6.52 \\
$\mathrm{Constituent}$ & ppm \\
$\mathrm{Cd}$ & $<3$ \\
$\mathrm{~Pb}$ & 30.1 \\
$\mathrm{As}$ & 66.2 \\
\hline
\end{tabular}

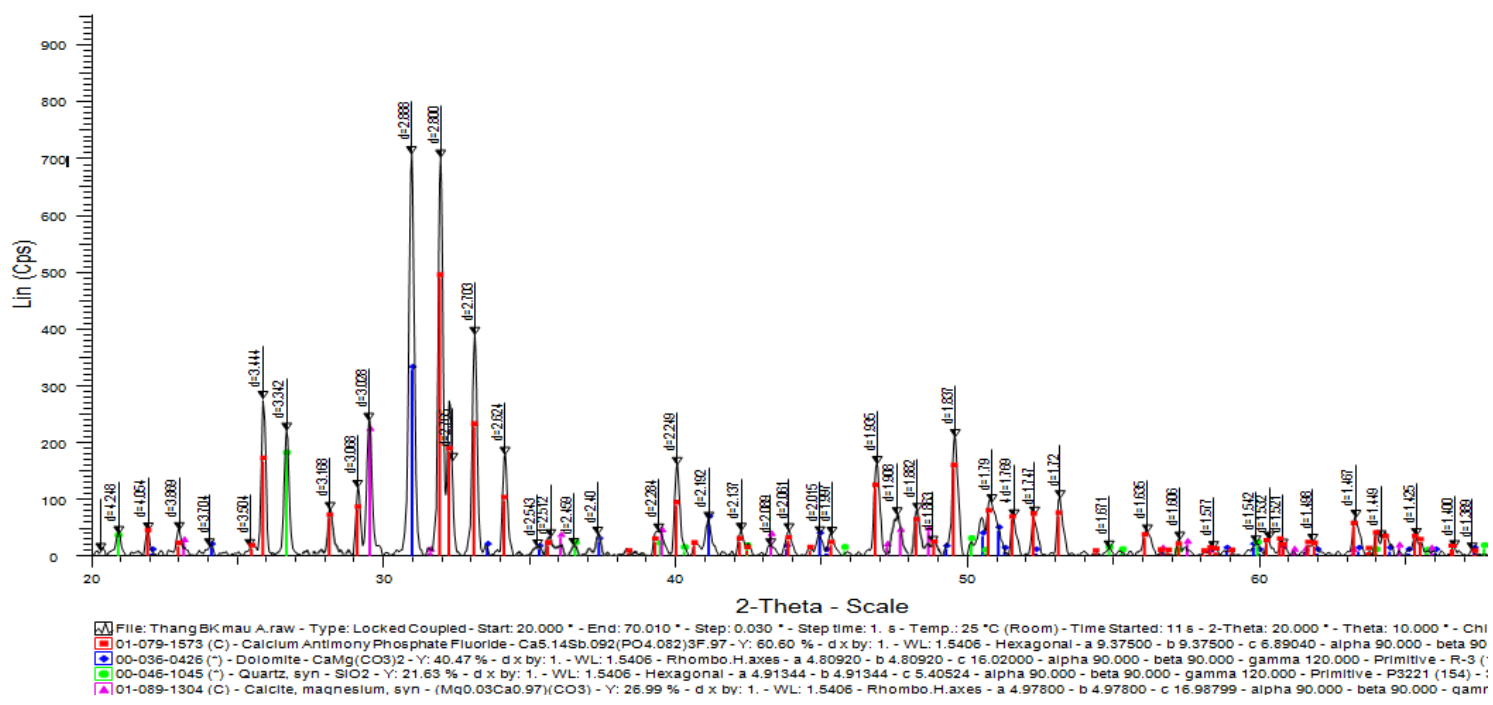

Figure 1. The XRD patterns of original Lao Cai second grade apatite ore from Unit CS-5 sample.

\subsection{Apparatus}

All reactions were carried out in a cylindrical $1 \mathrm{~L}$ reactor of $10 \mathrm{~cm}$ diameter. It was fitted with teflon-coated stirrer and placed in thermostatically controlled water bath. The impeller tip speed was adjusted at $400 \mathrm{rpm}$ unless otherwise stated. Filtration was performed using Buchner type filter of $11.61 \mathrm{~cm}$ diameter. Red color filter paper aperture size was used. A vacuum pump was used for filtration.

\subsection{Procedure}

The phosphate ore sample was crushed with a jaw crusher and sieved using ASTM standard sieves to collect various size fractions for analysis. All the sieved samples were dried in 
an electric oven at $105{ }^{\circ} \mathrm{C}$, cooled to room temperature and stored in a closed desiccator. These sample fractions were analyzed for $\mathrm{P}_{2} \mathrm{O}_{5}$ content as shown in Table 2 .

Table 2. Sieve analysis and $\mathrm{P}_{2} \mathrm{O}_{5}$ content of phosphate ore fractions.

\begin{tabular}{|c|c|c|c|c|}
\hline No. & Fraction Size, $\boldsymbol{\mu m}$ & Weight, $\mathbf{k g}$ & Recovery, $\%$ & $\mathbf{P}_{\mathbf{2}} \mathbf{O}_{\mathbf{5}}, \mathbf{w t .} \boldsymbol{\%}$ \\
\hline 1 & 1450 & 5.00 & 100.0 & 23.19 \\
\hline 2 & $1450-1000$ & 0.519 & 10.38 & 21.16 \\
\hline 3 & $750-710$ & 0.731 & 14.62 & 23.03 \\
\hline 4 & $600-500$ & 0.741 & 14.82 & 23.99 \\
\hline 5 & $420-315$ & 1.000 & 20.00 & 24.13 \\
\hline 6 & $315-250$ & 0.764 & 15.28 & 24.37 \\
\hline 7 & $250-160$ & 1.215 & 24.30 & 24.65 \\
\hline
\end{tabular}

For each run, $5 \mathrm{~g}$ of phosphate sample was transferred with the proper determined amount of hydrochloric acid solution into the reactor. Isoamyl alcohol (Defoamer) is added when necessary. After the desired reaction time, the leach slurry was immediately separated by filtration. The remaining solids were dried and weighted. In the filtrate, the $\mathrm{P}_{2} \mathrm{O}_{5}$ content was determined by a colorimetric method (spectrophotometer type Shimadzu UV 1208, ammonium molybdate and ammonium metavanadate were used for $\mathrm{P}_{2} \mathrm{O}_{5}$ analysis). $\mathrm{CaHPO}_{4}$ experiments were carried out by adding $4 \mathrm{~g}$ of calcium carbonate to the proper amount of acidulated solution into the reactor. After the desired reaction time, the produced DCP was filtrated, dried and weighted. $\mathrm{P}_{2} \mathrm{O}_{5}$ content was determined in both DCP and the precipitation raffinate solution by colorimetric method (spectrophotometer type Shimadzu UV 1208, ammonium molybdate and ammonium metavanadate were used for $\mathrm{P}_{2} \mathrm{O}_{5}$ analysis).

\section{RESULTS AND DISCUSSION}

\subsection{Effect of dilute hydrochloric acid on leaching behavior sample of Lao Cai second grade ore from Unit CS-5}

\subsubsection{Effect of particle size}

The effect of particle size on the phosphate ore leaching process was studied using particle size fractions $1300-1000,750-550,550-450,450-400,400-315,315-250,250-150$ and $160-63 \mu \mathrm{m}$. The results in Table 3 relating the $\mathrm{P}_{2} \mathrm{O}_{5}$ recovery $\%$ and particle size clarify that, the phosphate ore fractionation has a slight effect on the $\mathrm{P}_{2} \mathrm{O}_{5}$ recovery $\%$, where the difference in $\mathrm{P}_{2} \mathrm{O}_{5}$ recovery \% between the largest particle size $(450-400 \mu \mathrm{m})$ and the smallest $(160-63$ $\mu \mathrm{m})$ is less than $1 \%$. 
Table 3. Effect of particle size on $\mathrm{P}_{2} \mathrm{O}_{5}$ recovery \% from phosphate ore at $16 \mathrm{~min}, 25^{\circ} \mathrm{C}, 400 \mathrm{rpm}, 1.0 \mathrm{M} \mathrm{HCl}$ and $\mathrm{L} / \mathrm{S} 20 \mathrm{ml} / 5 \mathrm{~g}$.

\begin{tabular}{|c|c|}
\hline Fraction, $\mu \mathrm{m}$ & $\mathrm{P}_{2} \mathrm{O}_{5}$ leaching \% \\
\hline $1300-1000$ & 12.9 \\
\hline $750-550$ & 14.1 \\
\hline $550-450$ & 14.3 \\
\hline $450-400$ & 16.3 \\
\hline $400-315$ & 16.6 \\
\hline $315-250$ & 16.8 \\
\hline $250-160$ & 16.7 \\
\hline $160-63$ & 16.5 \\
\hline
\end{tabular}

Therefore, all investigations were carried out with particle size fractionation $\leq 450 \mu \mathrm{m}$ to cancel mid cost. The recovery $\left(\varphi\right.$, in \%) of $\mathrm{P}_{2} \mathrm{O}_{5}$ was calculated by the following equation:

$$
\varphi=100 \frac{\text { dissolved } \mathrm{P}_{2} \mathrm{O}_{5} \text { amount }}{\text { total } \mathrm{P}_{2} \mathrm{O}_{5} \text { amount in the rock }}
$$

The precipitation efficiency $(\chi, \%)$ was calculated by:

$$
\chi=100 \frac{\text { amount of } \mathrm{P}_{2} \mathrm{O}_{5} \text { in produced DCP }}{\text { total amount of } \mathrm{P}_{2} \mathrm{O}_{5} \text { in the acidulate solution }}
$$

\subsubsection{Effect of reaction time}

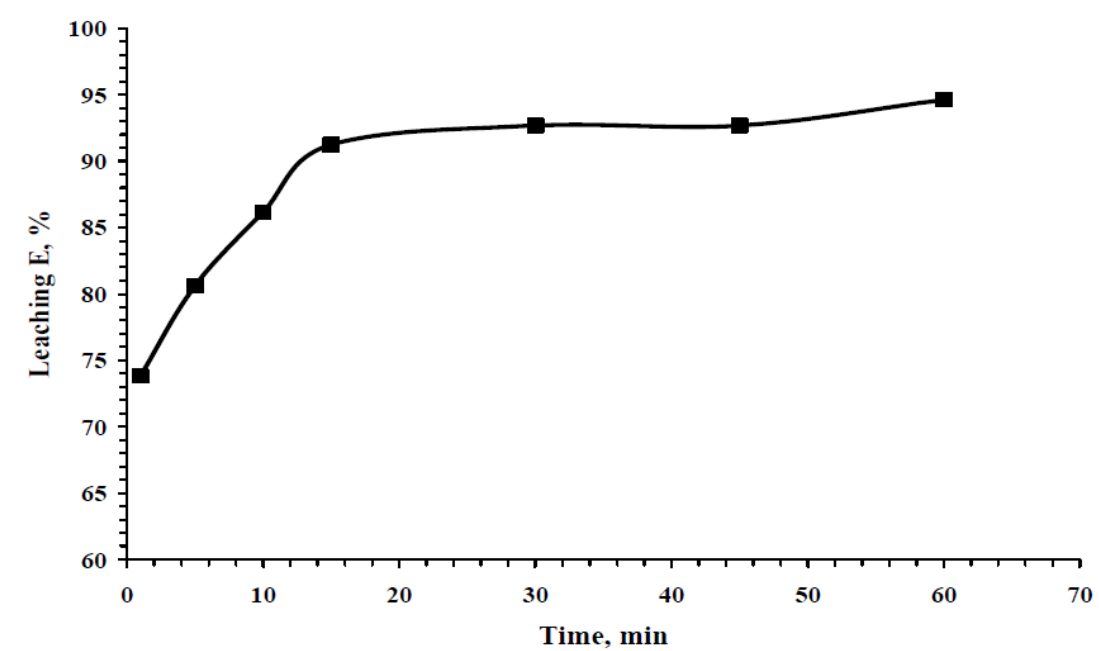

Figure 2. Effect of reaction time on $\mathrm{P}_{2} \mathrm{O}_{5}$ leaching \% from phosphate ores at room temperature, a stirring speed of $400 \mathrm{rpm}$, an acid concentration of $10 \%$, L/S mass ratio $25 \mathrm{ml} / 5 \mathrm{~g}$ and a particle size $\leq 450 \mu \mathrm{m}$.

To study the effect of leaching time on phosphate ore leaching by $10 \%$ hydrochloric acid, several experiments were carried at different times $(15-50 \mathrm{~min})$ at $25^{\circ} \mathrm{C}$; stirring speed of 400 
$\mathrm{rpm}$; L/S mass ratio of $25 \mathrm{ml} / 5 \mathrm{~g}$ and particle size $\leq 450 \mu \mathrm{m}$. The results given in Fig. 2 clearly show that, as the time increases from 2 to 15 min, the leaching $\%$ of $\mathrm{P}_{2} \mathrm{O}_{5}$ increases from 73.80 to $91.23 \%$ meaning that the reaction is fast. After $15 \mathrm{~min}$, there is a slight increase in the reaction $\%$.

Therefore, $15 \mathrm{~min}$ is taken as optimum to maximize the phosphate ore leaching by hydrochloric acid.

\subsubsection{Effect of reaction temperature}

The effect of reaction temperature on the leaching process was investigated at $25-60{ }^{\circ} \mathrm{C}$, $15 \mathrm{~min}, 400 \mathrm{rpm}$, acid concentration $10 \%$, particle size fraction $\leq 450 \mu \mathrm{m}$, and $\mathrm{L} / \mathrm{S}$ mass ratio $25 \mathrm{ml} / 5 \mathrm{~g}$. The results given in Fig. 3 indicate that the reaction temperature has a slight effect on the reaction rate. Therefore, room temperature $\left(25^{\circ} \mathrm{C}\right)$ is preferred for the leaching process.

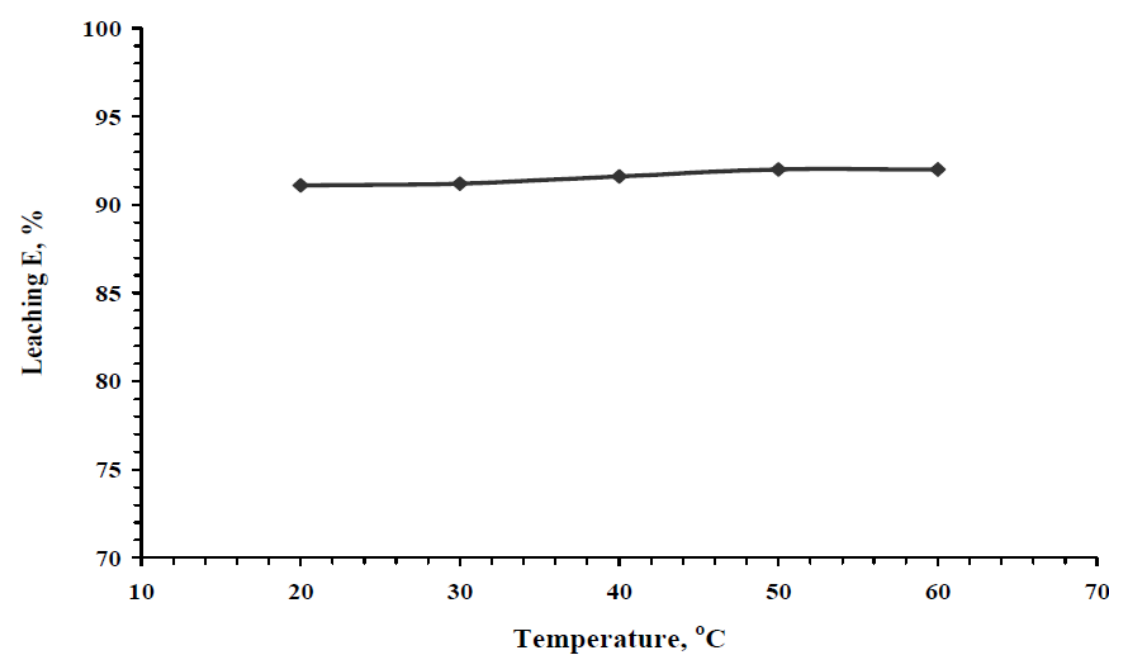

Figure 3. Effect of reaction temperature on $\mathrm{P}_{2} \mathrm{O}_{5}$ leaching $\%$ from phosphate ore for time $15 \mathrm{~min}$, a stirring speed of $400 \mathrm{rpm}$, an acid concentration of $10 \%$, $\mathrm{L} / \mathrm{S}$ ratio $25 \mathrm{ml} / 5 \mathrm{~g}$ and a particle size $\leq 450 \mu \mathrm{m}$.

\subsubsection{Effect of acid concentration}

The effect of hydrochloric acid concentration on the phosphate ore leaching process was studied at different concentrations $(2.5-20 \%)$ at $15 \mathrm{~min}, 400 \mathrm{rpm}, 25^{\circ} \mathrm{C}$, particle size fraction of $\leq 450 \mu \mathrm{m}$, and L/S of $25 \mathrm{ml} / 5 \mathrm{~g}$. The experimental results (Fig. 4) clarify that, as the acid concentration increases from $2.5-20 \%$, the $\mathrm{P}_{2} \mathrm{O}_{5}$ recovery increases from 20.63 to $91.23 \%$; further increase shows slight effect. This may be due to the fact that the increase of $\mathrm{H}^{+}$ concentration increases the number of collisions with $\mathrm{PO}_{4}^{-3}$ or the $\mathrm{H}^{+}$ions collisions with $\mathrm{PO}_{4}^{-3}$, $\mathrm{HPO}_{4}^{-2}, \mathrm{H}_{2} \mathrm{PO}_{4}^{-}$in aqueous phase. Therefore, $10 \%$ hydrochloric acid is preferred or the phosphate ore dissolution process. 


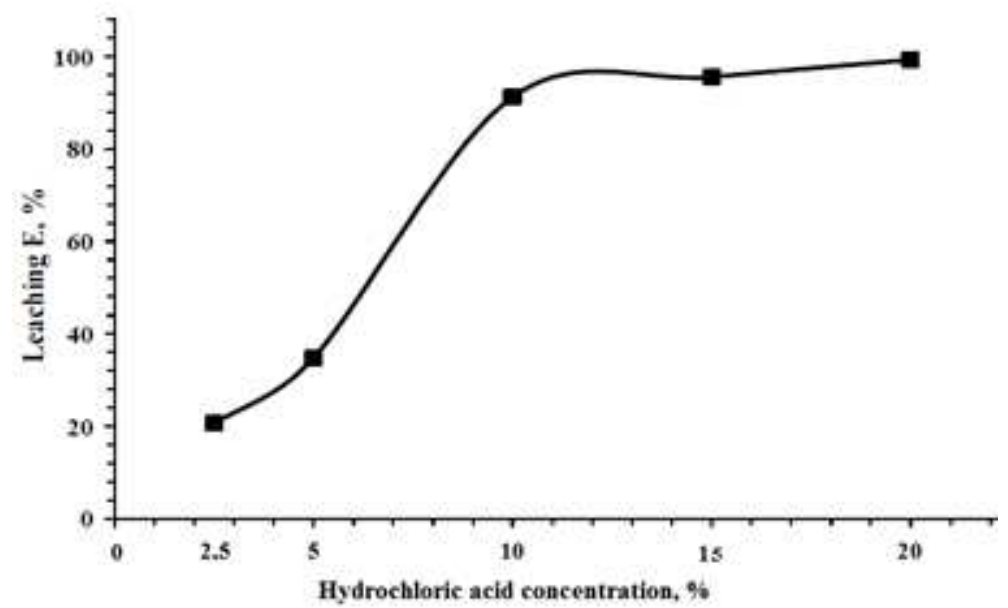

Figure 4. Effect of acid concentration on $\mathrm{P}_{2} \mathrm{O}_{5}$ leaching \% from phosphate ore at a room temperature, for time $15 \mathrm{~min}$, a stirring speed of $400 \mathrm{rpm}, \mathrm{L} / \mathrm{S}$ mass ratio $25 \mathrm{ml} / 5 \mathrm{~g}$, and a particle size $\leq 450 \mu \mathrm{m}$.

\subsubsection{Effect of stirring speed}

The leaching process was performed using $10 \%$ hydrochloric acid with different stirring speed ranging from 200 to $600 \mathrm{rpm}$ and reaction time of $15 \mathrm{~min}$, L/S mass ratio of $25 \mathrm{ml} / 5 \mathrm{~g}$, temperature $25{ }^{\circ} \mathrm{C}$ and particle size fraction of $\leq 450 \mu \mathrm{m}$ to study the effect of mechanical stirring speed on the leaching process. The results in Fig. 5 reflect slight effect. Accordingly, all experiments were carried out at $400 \mathrm{rpm}$.

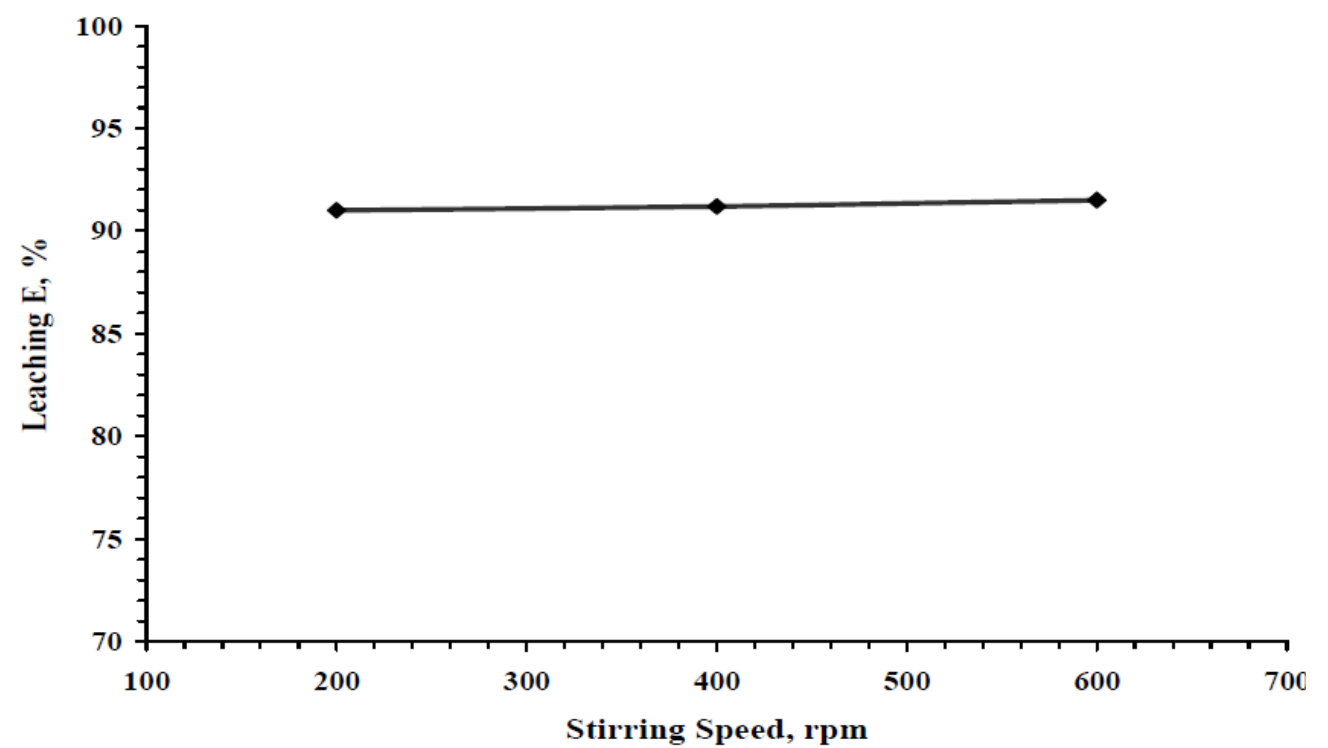

Figure 5. Effect of mixing stirring speed on $\mathrm{P}_{2} \mathrm{O}_{5}$ leaching \% from phosphate ore at L/S mass ratio $25 \mathrm{ml} /$ $5 \mathrm{~g}$, a room temperature, for time $15 \mathrm{~min}$, an acid concentration of $10 \%$, and a particle size $\leq 450 \mu \mathrm{m}$.

\subsubsection{Effect of $\mathrm{HCl} /$ phosphate rock mass ratio}

The effect of hydrochloric acid volume to phosphate ore mass ratio was studied within the range from $2 \mathrm{ml} / 1 \mathrm{~g}$ to $6 \mathrm{ml} / 1 \mathrm{~g}$. Figure 6 shows that, as the liquid/solid ratio increases from 2/1 
to $6 / 1$, the recovery $\%$ of $\mathrm{P}_{2} \mathrm{O}_{5}$ increases from 36.21 to $96.50 \%$ meaning that the decrease of bulk density (increase volume/solid ratio) increases the $\mathrm{P}_{2} \mathrm{O}_{5}$ leaching $\%$. The volume/solid mass ratio of $5 \mathrm{ml} / 1 \mathrm{~g}$ is the optimum ratio.

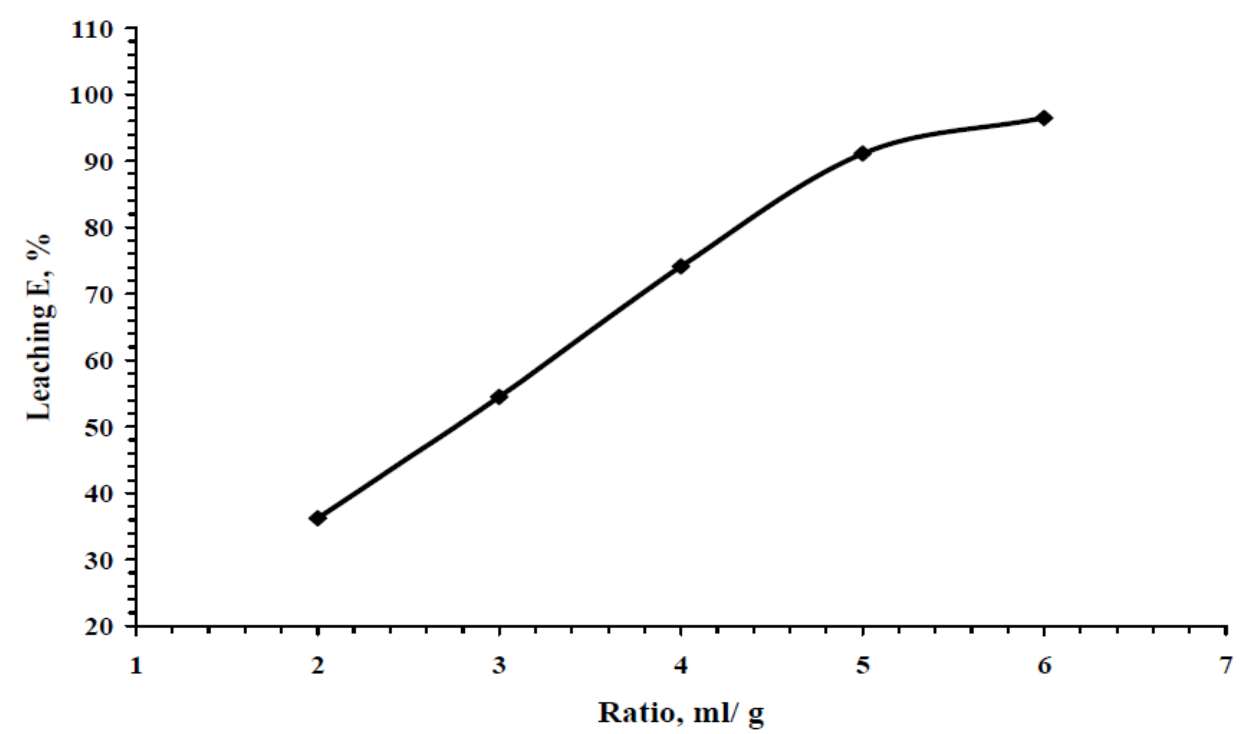

Figure 6. Effect of hydrochloric acid/phosphate ore ratio on $\mathrm{P}_{2} \mathrm{O}_{5}$ leaching $\%$ from phosphate ore at mixing stirring speed of $400 \mathrm{rpm}$, a room temperature, for time $15 \mathrm{~min}$, an acid concentration of $10 \%$, and a particle size $\leq 450 \mu \mathrm{m}$.

\subsection{Specification of leached $\mathrm{H}_{3} \mathrm{PO}_{4}$ and Precipitation of dicalcium phosphate}

From the aforementioned investigation on leaching Lao Cai second grade apatite ore from Unit CS 5 by hydrochloric acid, a leaching experiment was carried out at phosphate ore particle size $\leq 450 \mu \mathrm{m}$, leaching hydrochloric acid concentration of $10 \%$, L/S mass ratio $6 \mathrm{ml} / 1 \mathrm{~g}$, leaching reaction time $15 \mathrm{~min}$, and mixing speed $400 \mathrm{rpm}$ at room temperature. Accordingly, $500 \mathrm{ml}$ of $10 \%$ hydrochloric acid was added to $100 \mathrm{~g}$ of phosphate ore of particle size fraction of $\leq 450 \mu \mathrm{m}$ and stirring for $15 \mathrm{~min}$ at room temperature. After filtration with solid filter aid, the obtained acidulated solution was analyzed and the results obtained are given in Table 4.

Table 4. The chemical analysis of the produced acidulated phosphoric acid solution.

\begin{tabular}{|c|c|c|c|}
\hline Constituent & Mass, $\mathrm{g}$ & Constituent & $\mathrm{C}, \mathrm{ppm}$ \\
\hline $\mathrm{P}_{2} \mathrm{O}_{5}$ & 17.86 & $\mathrm{Cd}$ & 0.32 \\
\hline $\mathrm{MgO}$ & 5.61 & $\mathrm{~Pb}$ & 3.53 \\
\hline $\mathrm{F}$ & 0.81 & $\mathrm{As}$ & 5.80 \\
\hline
\end{tabular}

\subsection{Precipitation of dicalcium phosphate}

Calcium carbonate was used as calcium source to precipitate dicalcium phosphate from the produced acidic solution according to the following equation:

$$
\mathrm{CaCO}_{3}+\mathrm{H}_{3} \mathrm{PO}_{4}+\mathrm{H}_{2} \mathrm{O} \rightarrow \mathrm{CaHPO}_{4} \cdot 2 \mathrm{H}_{2} \mathrm{O}+\mathrm{CO}_{2} \uparrow
$$


The value $\mathrm{pH}$ of acidulated solution is one of the parameters affect the dicalcium phosphate precipitation efficiency.

\subsubsection{Effect of $\mathrm{pH}$ on the precipitation process of dicalcium phosphate from the produced acidic solution}

The precipitation of dicalcium phosphate from the produced acidic solution was studied at different $\mathrm{pH}$ values $(3.0-6.0)$. The obtained results are given in Fig. 7, which clarify that as the $\mathrm{pH}$ values increases $(3.0-5.0)$, the precipitation efficiency increases from 20 to $98.2 \%$ and further increase in $\mathrm{pH}$ values has a slight effect on the precipitation efficiency. During the subsequent neutralization, the $\mathrm{pH}$ is advantageously adjusted to a value of at least 4.5 , preferably at least 5. At this $\mathrm{pH}$, all the phosphate ions in solution in the aqueous phase, in the form of calcium dihydrogen phosphate (MCP), pass to the insoluble DCP state. Therefore, $\mathrm{pH}=5.0$ is preferred for dicalcium phosphate precipitation process.

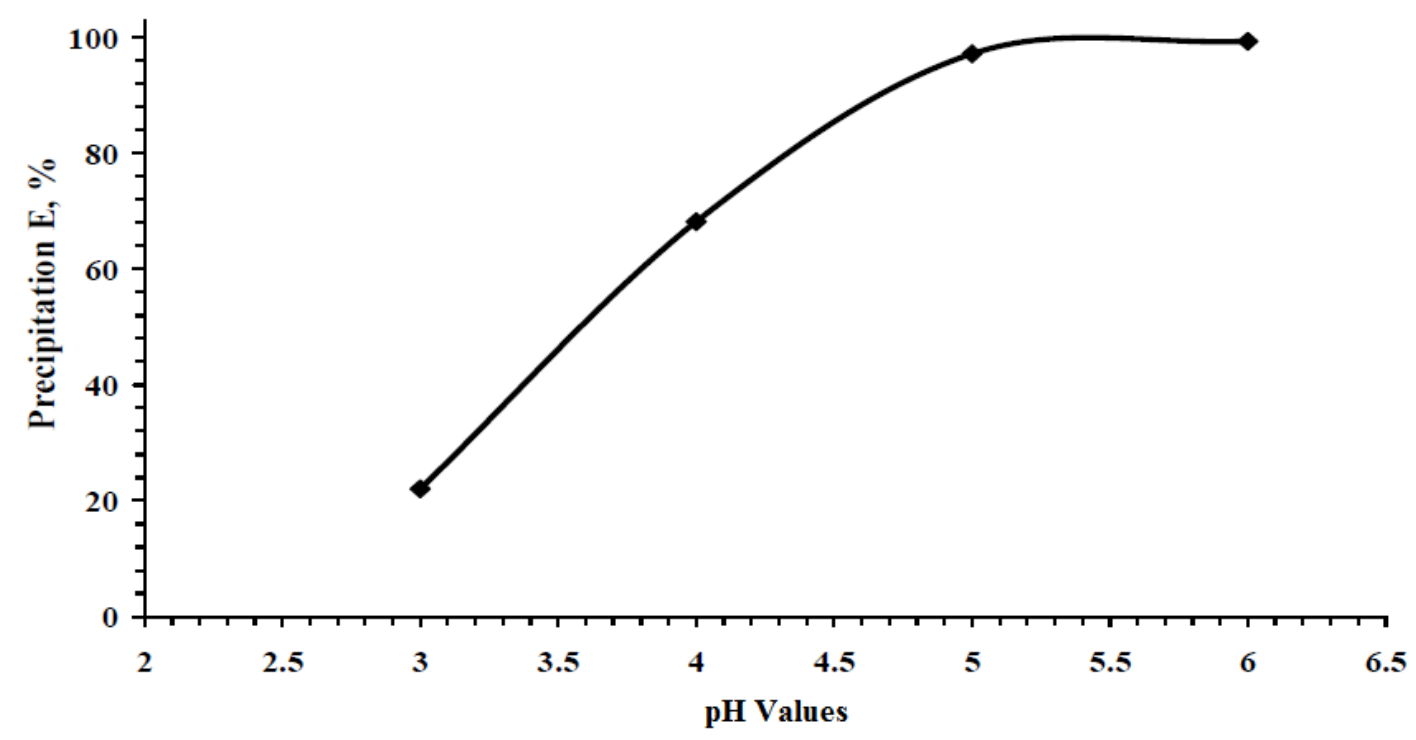

Figure 7. Effect of $\mathrm{pH}$ on the precipitation process of dicalcium phosphate.

\subsubsection{Developed DCP production flow sheet}

Based on the aforementioned investigation, a process for DCP production was developed. In this respect, $1000 \mathrm{ml}$ of the produced acidulate solution was reacted with $100 \mathrm{~g}$ of calcium carbonate by mixing at $400 \mathrm{rpm}$ for $15 \mathrm{~min}$ at room temperature. The precipitate was filtered and dried at $105{ }^{\circ} \mathrm{C}$ for $5 \mathrm{~h}$. Analysis of the product is given in Table 5 together with the standard quality of DCP given in the Vietnam National Standard TCVN 9471:2012.

From this table, it is clear that the specification of DCP produced by the developed method is in accordance with TCVN 9471:2012 specifications. 
Table 5. Dicalcium phosphate produced from addition of $100 \mathrm{~g}$ of calcium carbonate to $1000 \mathrm{ml}$ of acidulate solution for $15 \mathrm{~min}$ at room temperature and stirring speed was $400 \mathrm{rpm}$ according to TCVN 9471:2012 standard.

\begin{tabular}{|l|c|c|}
\hline \multicolumn{1}{|c|}{ Characteristic } & Produced DCP & Standard* \\
\hline $\mathrm{P}$ & $17.5 \%$ & $16.5 \% \mathrm{~min}$. \\
\hline $\mathrm{Ca}$ & $22.0 \%$ & $20.0 \% \mathrm{~min}$. \\
\hline $\mathrm{F}$ & $0.10 \%$ & $0.2 \% \mathrm{max}$. \\
\hline $\mathrm{As}$ & $3.5 \mathrm{mg} / \mathrm{kg}$ & $30 \mathrm{mg} / \mathrm{kg} \max$. \\
\hline $\mathrm{Pb}$ & $2.5 \mathrm{mg} / \mathrm{kg}$ & $30 \mathrm{mg} / \mathrm{kg} \max$. \\
\hline $\mathrm{Cd}$ & $2.0 \mathrm{mg} / \mathrm{kg}$ & $10 \mathrm{mg} / \mathrm{kg} \max$. \\
\hline Particle size $\leq 500 \mu \mathrm{m}$ & $96.0 \%$ & $95.0 \% \min$. \\
\hline Moisture & $3.0 \%$ & $7.0 \% \mathrm{max}$. \\
\hline
\end{tabular}

* According to TCVN 9471:2012 standard.

\section{CONCLUSION}

The preferred leaching conditions for Lao Cai second grade apatite ore from Unit CS 5 of particle size $\leq 450 \mu \mathrm{m}$ were hydrochloric acid $(10 \%)$, temperature $\left(25{ }^{\circ} \mathrm{C}\right)$, hydrochloric acid/phosphate ore mass ratio $(5 \mathrm{ml} / 1 \mathrm{~g})$, stirring speed $(400 \mathrm{rpm})$ and mixing period (15 min). The leaching efficiency was $96.5 \%$. Dicalcium phosphate from the produced acidulate solution was successfully precipitated using calcium carbonate. The precipitation efficiency was $96.8 \%$ using acidulate solution/calcium carbonate mass ratio of 10 , stirring time of $15 \mathrm{~min}$, stirring speed of $400 \mathrm{rpm}$ and at $25{ }^{\circ} \mathrm{C}$. The specification of the produced DCP is in accordance with the TCVN 9471:2012 specifications.

Acknowledgements. This research is funded by Vietnam Academy of Science and Technology \& People's Committee of Lao Cai Province and AT JSC, code: VAST.NĐP.12/13-14.

\section{REFERENCES}

1. Emich G. D. - Phosphate Rock, Industrial Minerals and Rocks 2 (1984) 1017-1047.

2. Jasinski S. M. 2007 - Phosphate Rock, U.S. Geological Survey, Mineral Commodity Summaries (2007) 120-121

3. Mohamed I. Al-Wakeel -, Effect of mechanical treatment on the mineralogical constituents of Abu-Tartour phosphate ore, Egypt, International Journal of Mineral Processing 75 (2005) 101-112.

4. Adel A. El-Zahhar, Mohsen M. Aly, Ahmed M. Ahmad, Magdy I. Khalifa, Ahmed A. ElAsmy, - Production of Calcium monohydrogenphosphate from Sebaiya phosphate ore leached by nitric acid, Eur. Chem. Bull. 2 (2013) 752-757.

5. Rashad M. M., Mahmoud M. H. H, Ibrahim I. A. and Abdel-Aal E. A. -, Crystallization of calcium sulfate dihydrate under simulated conditions of phosphoric acid production in 
the presence of aluminum and magnesium ions, Journal of Crystal Growth 267 (2004) 372-379.

6. Rashad M. M., Mahmoud M. H. H., Ibrahim I. A. and Abdel-Aal E. A. - Effect of citric acid and 1,2-dihydroxybenzene 3,5-disulfonic acid on crystallization of calcium sulfate dihydrate under simulated conditions of phosphoric acid production, Cryst. Res. Technol. 40 (2005) 741-747.

7. Abdel-Aal, E. A. - Crystallization of phosphogypsum in continuous phosphoric acid industrial plant, Crystal Research and Technology 39 (2004) 123-130.

8. Mahmoud M. H. H, Rashad M. M, Ibrahim I. A. and Abdel - Aal E.A. - Crystal modification of calcium sulfate dihydrate in the presence of some surface-active agents, Journal of colloid and interface science 270 (2004) 99-105.

9. Mohamed Takhim, US 20050238558 A1, 2005.

10. Zafar Iqbal Zafar, Ansari Tariq Mahmood, Ashraf Mohammad, Abid Mohammad Amin Effect of hydrochloric acid on leaching behavior of calcareous phosphorites, Iran. J. Chem. Chem. Eng. 25 (2006) 47-57.

11. Mohamed Takhim, US 20070122326, 2007.

12. The Department of Geology and Minerals of Vietnam (eds), Vietnam mineral resources, Hanoi 2000, p139. 